\title{
Effect of Remediation Activities on Grade 5 Pupils' Academic Performance in Technology and Livelihood Education (TLE)
}

\author{
John Mark R. Asio ${ }^{1 \star}$, Edward C. Jimenez ${ }^{2}$
}

${ }^{1}$ Gordon College, Olongapo City, PHILIPPINES

${ }^{2}$ Department of Education, Division of Meycauayan City, Bulacan, PHILIPPINES

*Corresponding Author: asio.johnmark@gmail.com

Citation: Asio, J. M. R., \& Jimenez, E. C. (2020). Effect of Remediation Activities on Grade 5 Pupils' Academic Performance in Technology and Livelihood Education (TLE). Pedagogical Research, 5(4), em0075. https://doi.org/10.29333/pr/8464

\begin{tabular}{|c|c|}
\hline ARTICLE INFO & ABSTRACT \\
\hline Received: 26 May 2020 & This study assesses the effectiveness of remediation activities of Grade 5 pupil's academic performance in the \\
\hline Accepted: 17 Jul. 2020 & $\begin{array}{l}\text { subject Technology and Livelihood Education (TLE). The study used an experimental pretest-posttest design. We } \\
\text { chose two schools in the experiment and each school has a class with } 50 \text { pupils each. We assigned one school as } \\
\text { the independent group and the other one was the experimental group. The researchers worked with the respective } \\
\text { teachers in TLE to determine the level of academic performance of the students. First, we administered a pretest } \\
\text { during their first grading period. The results for both schools were not impressive, prompting the researchers to } \\
\text { advise remediation activities to the experimental group. We advised the independent group to do the usual } \\
\text { learning methods. After the intervention, the researcher performed another set of assessment using the results of } \\
\text { the second grading period performance. The researchers used a paired t-test to check for significant differences } \\
\text { in the scores of the groups. The study found that there is a significant difference in the scores of the pupils after } \\
\text { the remediation intervention. Therefore, the researchers concluded that remediation activities can affect the } \\
\text { academic performance of the students. }\end{array}$ \\
\hline
\end{tabular}

Keywords: remediation activities, grade 5 pupils, academic performance, technology and livelihood education (TLE), paired t-test

\section{INTRODUCTION}

Educating pupils is the core reason for all teaching-learning processes which is undertaken in each classroom in the formal education platform. However, not all the students can accommodate the learning processes and this result with different outcomes. With this in mind, teachers need to create an intervention plan and not let these other students fall behind and still catch up with the lessons being discussed. A remedial class is always an impressive way to solve this common problem. That is why Thilges and Schmer (2020) provided a concept analysis of formal remediation wherein he established a framework for defining the concept, developing measurable outcomes, and describing when to implement the intervention. This is important so that there is a consistent and systematic way of delivering the remedial class. However, Caras (2019) states that there is still a need for direct instruction for students necessary to connect experiences knowing that they are learning. Students learn from various experiences that is why traditional teaching is still accepted and proven to be still effective through time. In this context, Mbwiri (2016) concluded that the constructivist approach was not superior to the traditional approach of instruction on a 10-week remedial class. This means that approaches to remedial classes can vary depending on the students, environment, and the teachers themselves. There are some learners who perform very poorly in their academic subjects. They commit some of these learners to absenteeism because of family issues, financial problems, social matters, and other related issues. Sultan (2019) described the characteristics of remedial students like these, which includes attendance problem, lack of focus during the learning process, health and learning problems, not giving response when questions are asked by the teacher, lack of interest in learning, and family problems.

Pupils' Academic Performance is the basis on how teachers start remediation activities to their pupils through interventions and strategized methods of increasing student retention of learning. Jackson (2016) found out that instructors who conducted remediation used instructional techniques that matched effective practices found in the current research literature. Everyone opt for teachers to give remediation until such time that learners are back on track. As Capuyan et al. (2019) revealed, there is a positive relationship between the previous and the current grade levels' grades of pupils attending remediation lessons. In relation, Tseng et al. (2016) also mentioned that remedial interventions by teaching advisors showed a great impact on students' improvement 
of final grades. Everybody rendezvous schools for learning and experience both for teachers and learners. Each of them goes to school every day for the best learning experience to happen.

There are original studies that have been published which provide conflicting results regarding the effectiveness of a remedial class. For instance, Triviño in 2016 showed a marked improvement in the students' assessment scores and in their participation in the remedial and regular classes after the conduct of intervention. In addition, Balinas et al. (2017) also revealed a favorable impact on participants' performance as evidenced by a significant difference in their pretest and posttest results. However, Sommerhalder (2018) contradicts these results, as he demonstrated in his study that there were no observable increases in the (Mathematics) academic performance of students after intervention materials were put into place. Furthermore, Wang et al., (2017) stated that the efficacy of remediation remains one of the thorniest issues in research and practice. Remediation classes still need more substantial evidence to prove its effectivity especially on the changing tide of time processes of learning.

In the course of the discussion, there are also other literatures that provided essential results and yielded some promising results. The idea of remediation class can be applied to any subject and the following studies proved to have valuable insights. Subject areas where remedial classes showed remarkable results include, but not limited to, the following subjects: computerassisted instructions (Chaturvedi, 2016), English (Bansal \& Deepika, 2017), Mathematics (Kelly, 2018; Lundberg et al., 2018), Science (Lin \& Liu, 2017) Statistics and Algebra (Logue, 2016), and reading comprehension (Hasan \& Ahmad, 2019).

Learners are the core of the education process, which entails day-to-day activities and performances. Teachers need to do extra efforts to supplement their teachings from time to time and Jimenez (2020) identified ten factors that motivate teachers to develop supplementary learning materials. Most of these students attend their everyday classes to pass their assessments that will assure them that learning is essentially understood. Remediation activities as one guarantee educational assistance to those children who are low performers and absentees. This ensures better academic performance for all the children who are at risk of dropping out and failing. Besides, Stevens (2018) resolved that an intervention integrating both the growth mindset and stress mindset is not more effective than a single growth mindset in assisting middle school students with either outlook.

In the Schools Division of Meycauayan City, low academic performance is observed among pupils in Technology and Livelihood Education (TLE) and other subjects. In fact, the division overall rating in the previous National Achievement Test is $68.36 \%$. This result is far from the minimum passing rate of $75 \%$. This is the main reason the researcher decided to conduct this study to augment the schools' initiatives to increase their academic standing. Remediation provides avenues to acquire the competencies that our learners needed to be equipped and ready for the next step of their endeavor. Similarly, James (2018) suggested that remediation efforts of one-on-one student tutorials and after-school tutorial programs focused on core subject areas and informed by the leadership philosophy of an administrator strongly contributed to student achievement.

Because of the conditions that our learners face as they miss opportunities to fully acquires the learning competencies, this study was conducted to help every learner have a chance to master different competencies of their subject.

The researchers believe that the use of this remediation will help increase the academic performance of pupils in a particular subject. This will support each pupil to master the competencies required in the subject and at the same time, shall be able to increase the division overall rating.

\section{STATEMENT OF THE PROBLEM}

The primary purpose of this study is to assess the effectiveness of remediation activities to the academic performance of grade 5 pupils in the two schools in the Schools Division of Meycauayan City.

Specifically, this study sought to answer the following problems:

1) What is the level of pupils' academic performance in Technology and Livelihood Education (TLE) before and after the conduct of remediation activities?

2) Is there a significant difference in the academic performance of pupils after the remediation activities?

\section{METHODOLOGY}

\section{Design}

This study employed the experimental pretest-posttest design of research. The TLE teachers conducted the actual remediation processes to augment the pupils' academic performance and employ a posttest to check the validity of remediation activities. The researchers gathered data to interpret using the results of the pretests and posttests given by the TLE teachers to measure any significant difference.

\section{Participants}

The participants include fifty (50) Grade 5, pupils of Saluysoy Central School (SCS) which was considered for the experimental group and fifty (50) Grade 5 pupils of Malhacan Elementary School (MES) for the control group. Both schools are located in Meycauayan City, Bulacan. The two schools were chosen via purposive sampling. Both are central schools with large number of pupils representing the east district and west district of the division. Each class contains 50 pupils only. The chosen participants were randomly selected from the five sections of each school. After determining the section that will participate in the study, the TLE teachers were informed regarding the objective of the study and preceded with the learning. 
Table 1. Pupils' Level of Academic Performance before Remediation

\begin{tabular}{cccc}
\hline School & Overall Score & Percentage & Descriptor \\
\hline MES (Independent Group) & 31.48 & 53 & Did not meet Expectations \\
\hline SCS (Experimental Group) & 32.82 & 55 & Did not meet Expectations \\
\hline
\end{tabular}

Legend: $90-100=$ Outstanding

85-89 = Very Satisfactory

80-84 = Satisfactory

75-79 = Fairly Satisfactory

74 below $=$ Did not meet Expectations

\section{Data Collection}

The researcher requested the principals to meet the teachers involved having a formal meeting about the conduct of the research and later, disseminated it to the pupil-participants.

One of the researchers talked to the teachers involved and sought the result of the first quarter assessments. With the low results of the pupils' first-quarter tests, the researcher suggested the use of remediation activities in class.

The MES used the same method of teaching and followed the usual activities provided in the learning modules, while SCS used the remediation activities which entail the modification of activities based on the types of learners. The TLE teacher of the experimental group and the researchers brainstormed on the different types of remediation activities to be used in the entire quarter for the Grade 5 pupils of the experimental group. As a result, the use of graphic organizers, semantic web, checklist, and others was utilized for the set of intervention activities.

The current learners' module provides certain activities which necessitate a common type of learner and does not give additional activities to capacitate learners below the mastery level. While remediation activities create sound-friendly activities well-suited to the learners, this can help low performing learners to understand and master the competency for each lesson.

Remediation activities were given to the learners who did not meet the requirements to pass a particular summative assessment and were below the mastery level. This was administered every after class hour, or brought home by the learners so they can be assisted by their family members. As learners returned to school, the teacher checked the output and let the learners assess their work. This became the routine of the respondents who did not master the twenty-five (25) learning competencies of TLE for the entire second quarter.

To get the equivalent score of the remediation, the score of the learners' previous assessment was added to the newest score of the remediation and was divided into two. This made the new raw score of the learner in a particular lesson. It was noted that the remediation must equate the total number of items of the previous assessment given by the teacher.

The researchers used the Remediation Activity Approach as stipulated in Department of Education (DepEd) Order No. 73, Series of 2012, titled "Guidelines on the Assessment and Rating of Learning Outcomes under the K to 12 Basic Education Curriculum" for the administration of the study.

\section{Statistical Analysis}

The result of this study was tabulated and treated statistically using Microsoft Excel. A frequency count of the responses of the participants was treated fairly.

This research employed a paired sample t-test to describe any significant difference between the two groups using a pre and posttest methods. The researchers used the software, Statistical Package for Social Sciences (SPSS) version 20 to analyze the gathered data for the study. The Pretest raw scores of the first quarter quizzes were compared and analyzed based on the computed t-value. Likewise, the posttest raw scores of the second quarter quizzes were analyzed.

\section{RESULTS}

The main purpose of this study is to assess the effectiveness of remediation activities to the Grade 5 pupils' academic performance. It looked into the academic performance of pupils by the quizzes provided in their subject Technology and Livelihood Education (TLE). The results in Table 1 obtained from the study are hereby presented.

Table 1 presents the pupils' level of academic performance before the remediation. As seen, both schools scored very low in their preliminary quizzes during their first grading period. The overall score for each class was converted into percentages and interpreted using the descriptor provided by the Department of Education. As observed, both schools got a descriptor interpretation of "did not meet expectations". This means that students are still beginning to grasp the basic contexts of the subject and are still adjusting with the curriculum requirements and activities.

Table 2 presents the pupils' level of academic performance after the remediation on their second grading period. As observed, there is a slight improvement in scores from the independent group even when no remediation was performed. However, their scores still fall under the descriptor interpretation of "did not meet expectations". In contrast, remediation was done with the experimental group and their overall scores improved drastically and gained a descriptor interpretation of "outstanding". This means that the remediation activities of the experimental group have somehow affected the academic performance of the pupils. 
Table 2. Pupils' Overall Level of Academic Performance after Remediation

\begin{tabular}{cccc}
\hline School & Overall Score & Percentage & Descriptor \\
\hline MES (Independent Group) & 34.30 & 57 & Did not meet Expectations \\
\hline SCS (Experimental Group) & 54.44 & 91 & Outstanding
\end{tabular}

Legend: $\quad 90-100=$ Outstanding

85-89 = Very Satisfactory

80-84 = Satisfactory

75-79 = Fairly Satisfactory

74 below $=$ Did not meet Expectations

Table 3. Paired t-test for the Pupils' Academic Performance before Remediation Intervention

\begin{tabular}{lllllll}
\hline & Mean & N & SD & t value & $\boldsymbol{p}$ value \\
\hline MES (Independent Group) & 31.58 & 50 & 2.241 & \multirow{2}{*}{-1.040} \\
\hline SCS (Experimental Group) & 32.82 & 50 & 8.544 & \\
\hline
\end{tabular}

$\overline{d f=49}$

$p>.05$

Table 4. Paired T-test for the Pupils' Academic Performance after the Remediation Intervention

\begin{tabular}{|c|c|c|c|c|c|}
\hline & Mean & $\mathbf{N}$ & SD & $t$ value & $p$ value \\
\hline MES (Independent Group) & 34.40 & 50 & 1.389 & \multirow{2}{*}{-24.601} & \multirow{2}{*}{$.000^{\star}$} \\
\hline SCS (Experimental Group) & 54.44 & 50 & 5.414 & & \\
\hline
\end{tabular}

$d f=49$

${ }^{*} p<.05$

Table 3 presents the paired $t$-test for the significant difference in the overall mean scores of the two compared groups based on their academic performance during the first grading period. The researcher inferred that the academic performance of both groups did not vary that much as the mean of the independent group $(M=31.58 ; S D=2.241)$ is not far from the experimental group $(M=32.82 ; \mathrm{SD}=8.544)$. Since $t(49)=-1.040, \mathrm{p}=.303$, with the $p$-value being higher than the Alpha level of significance of .05 . It is safe to assume that there is no significant difference in the academic performance of the independent group and experimental group before the remediation activities.

Table 4 presents the paired t-test for the significant difference in the overall mean scores of the two groups based on their academic performance during the second grading period. It is deduced that there is a significant difference between the mean scores of the independent group $(\mathrm{M}=34.40 ; \mathrm{SD}=1.389)$ and experimental group $(\mathrm{M}=54.44 ; \mathrm{SD}=5.414)$, since $t(49)=-24.601, p=.000$ with the $p$-value is lower than the Alpha significance level of .05. Thus, it is safe to assume that there is a significant difference in academic performance when there is a remediation intervention performed.

\section{DISCUSSION}

The purpose of this study is to assess the effectiveness of remediation activities to the pupil's academic performance. Based on the results of the study, there is a parallel perspective based on the literature that was reviewed and evaluated. It also provided real evidence that would support the concept of improving the method and delivery of remediation activities and creative ways remediation intervention.

To start with, the researcher first assessed the learners' knowledge of particular topics which is covered during the first grading period. As a result, both the independent group and the experimental group did not do very well based on the scores of their quizzes obtained during the first grading period. After deciding that a remediation intervention is necessary, the researcher proceeded to do remediation activities for the experimental group. This type of approach is anchored on the Theory of Constructivism of Bruner (1966), in which all activities are based on observation and scientific study of what the learners did not meet during the discussion. As expected, there is a drastic change in the academic performance of the students in the experimental group compared to the independent group where no intervention is done. The experimental group's overall mean score was higher in the second grading period compared with that of the independent group's which only improved by a few points.

Finally, the researcher subjected the scores of both the independent and experimental group to statistical analysis to compare whether there is a significant difference in the academic performance after the remediation intervention was performed. As expected, substantial evidence that remediation activities have an effect on the academic performance of the students in the experimental group was observed. The result of the current study is parallel to other studies that also provided positive results: Lin and Liu (2017), Radzi et al. (2017), Vandenbussche et al. (2018), Zygouris et al. (2017), Dabkowska and Snovski (2016). However, there are also studies that contradict the ideas of the effectiveness of remediation activities. (Kelly, 2018; Sommerhalder, 2018) The result of this study will be considered by others since it also has a unique trait that provided another perspective in dealing with the idea of remediation interventions to help improve the performance of students regardless of whether they belong to the grade school or even in the higher level of learning such as in college.

In a different perspective about remediation activities, Yolak et al. (2019) revealed that remedial courses had academic, social, psychological, economic, and career development impacts on students' lives. Furthermore, Bale (2016) argued that children should be provided with systematic brain-based differentiated instructions. In another study, Lombardi (2019) pointed out that teachers barely assigned to remediation improve their pedagogical practices. These studies, along with the conducted research, 
prove that remediation activities to pupils are an effective tool that improves their academic performance. These mentioned ideas, however complex and complicated to some extent are contemporary sources of vital information that would help teachers apply the context of remediation. This study is unique in a sense since it is applied in a different subject primarily. At the same time, it used two different types of groups to analyze the effect of remediation on the students. Thus, the result of this study somehow contributes to the growing number of literature that would give real ideas to future researches and researchers.

\section{CONCLUSION}

Based on the result of the study, it is observed that remediation and intervention have a significant impact on the academic performance of pupils. This is so since there is a significant difference in the scores between the independent group and the experimental group after the intervention as reflected in their performance through various quizzes. Thus, it is safe to end that remediation interventions can effectively improve pupils' academic performance. However, just like in any other researches, this study also has its limitations. First is the number of respondents, since the researchers were limited to one section per school. The result could be more reliable if there were more participants included in the study. Secondly, the duration of the study only covered two grading periods, because it could have been more practical if the measures were done for the school year to decide if the intervention really worked out substantially for the students who participated in the study. Third is the scope of the research, as the study only considered one aspect of evaluation, which is the quiz. There are other ways to measure the real impact of remediation activities like grading examinations or unit tests, achievement tests, and the like. Lastly, it is only done in one subject TLE, in which the results may not be the same with other subjects. The future research direction of this study includes the idea of using remediation activities with other subjects other than TLE. Remediation activities can also be used not only in the elementary levels but also in the junior and senior high school or even in the college level. Remediation activities can help students augment their learning behavior and achieve their goals in their studies.

\section{RECOMMENDATIONS}

In the light of the conclusions drawn, the following recommendations are hereby drawn out by the researcher:

1. TLE teachers should adapt the use of remediation activities as a part of teaching methodology of teacher to increase pupils' performance;

2. Teachers should continuously attend more trainings and seminars on different teaching strategies in TLE for better teaching competency;

3. School heads should continuously follow-up the implementation of remediation activities and make a constant checking of teacher's remediation notebook;

4. School heads may include remediation workload in their School Learning Action Cell (SLAC) for the promotion of higher academic performance of learners in all subject areas; and

5. Education Program Supervisors may use and adapt this strategy for the promotion of higher academic perspective.

\section{REFERENCES}

Bale, J. B., Chen, S. H. A., Tan, S. C., Poon, K., Fitzeer, K. R., \& Boyd, L. A. (2016). Reconciling individual differences with collective needs: The juxtaposition of sociopolitical and neuroscience perspectives on remediation and compensation of student skill deficit. Trends in Neuroscience and Education, 5(2), 41-51. https://doi.org/10.1016/j.tine.2016.04.001

Balinas, E. S., Rodriguez, J. R., Santillan, J. P., \& Valencia, Y. C. (2017). Remedial reading program of AUF-CED: Best practices and impact. Advances in Social Science, Education and Humanities Research, 109,83-93. https://doi.org/10.2991/aecon-17.2017.18

Bansal, P., \& Deepika. (2017). The effectiveness of English remedial program: A case study. The Educational Beacon, 1(6), $30-35$. Retrieved from http://theeducationalbeacon.com/images/the_effectiveness.pdf

Bruner, J. (1966). Toward a theory of instruction. Cambridge, MA: Harvard University Press.

Capuyan, D., Etcuban, J. O., Manguilimotan, R., Padillo, G., Raynera, W., \& Onrejas, E. (2019). Mathematics remedial program for elementary learners in Cebu City, Philippines. American Research Journal of Humanities Social Sciences, 2(5), 16-23. Retrieved from https://www.arjhss.com/wp-content/uploads/2019/05/D251623.pdf

Caras, K. L. (2019). The Effectiveness of Inquiry and Computer Based Learning in Remediation of Science Students (Doctoral Dissertations), Liberty University, Lynchburg, VA, USA. https://digitalcommons.liberty.edu/doctoral/2177

Chaturvedi, S. (2016). Effectiveness of computer assisted instruction for remedial teaching of children with cognitive learning disabilities. Journal of Socio-Educational \& Cultural Research, 2(5), 27-34. Retrieved from http://www.jsecrjournal.com/journal/14850554681935904763.pdf

Dabkowska, E., \& Sosnovski, B. (2016). Remedial-Math workshop: Opening doors to graduation. Community College Journal of Research and Practice, 40(11), 954-960. https://doi.org/10.1080/10668926.2015.1132645 
Hasan, R., \& Ahmad, N. A. (2019). Needs analysis of Scaffolding Literacy (ScafoLIT) module in helping remedial students mastering reading comprehension skills. International Journal of Academic Research in Business \& Social Sciences, 9(1), 284-295. Retrieved from https://doi.org/10.6007/IJARBSS/v9-i1/5397

Jackson, Y. D. (2016). Health science administrators' perceptions of remediation with students in professional-track programs (Doctoral Dissertations), Walden University, Minneapolis, MN, USA. https://scholarworks.waldenu.edu/dissertations

James, F. H. (2018). A case study of instructional leadership, remediation, and student success in Algebra I in four public high schools (Doctoral Dissertation), University of Arkansas at Little Rock, Little Rock, AR, USA. Retrieved from https://search.proquest.com/openview/a78875795d9bb2eae8a39f6a65a2c609/1?pq-origsite=gscholar\&cbl=18750\&diss=y

Jimenez, E. C. (2020). Motivating factors of teachers in developing supplementary learning materials (SLMS). International Journal of Advanced Research, 8(5), 108-113. https://doi.org/10.21474/IJAR01/10912

Karakonstantaki, E. S., Simos, P. G., Michalis, V., \& Michelovannis, S. (2017). Assessment and conceptual remediation of basic calculation skills in elementary school students. British Journal of Developmental Psychology, 36(1), 78-97. https://doi.org/10.1111/bjdp.12214

Kelly, S. (2018). The impact of khan academy math remediation on ninth grade student achievement (Doctoral Dissertation), Liberty University, Lynchburg, VA, USA. https://digitalcommons.liberty.edu/doctoral/1694

Lin, S. W., \& Liu, Y. (2017). A diagnostic-remediation teaching system for enhancing elementary students' science listening comprehension. International Journal of Science and Mathematics, 15, 1485-1500. https://doi.org/10.1007/s10763-016-9756-4

Logue, A. W., Rose, M. W., \& Douglas, D. (2016). Should students assessed as needing remedial Mathematics take college-level quantitative courses instead? A randomized controlled trial. Education Evaluation and Policy Analysis, 38(3), 578-598. https://doi.org/10.3202/0162373716649056

Lombardi, M. (2019). Is the remedy worse than the disease? The impact of teacher remediation on teacher and student performance in Chile. Econmics of Education Review, 73, 101928. https://doi.org/10.1016/j.econedurev.2019.101928

Lundberg, T., Conrad, L., Gasman, M., Nguyen, T.-H., \& Commodore, F. E. (2018). Practices of remedial Mathematics students who succeed in college: A case study of developmental Math education at Chief Dull Knife College. The Review of Higher Education, 42(1), 61-101. Retrieved from https://muse.jhu.edu/article/704813

Mbwiri, F. I. (2016). Remedial Math instruction intervention: Efficacy of constructivist practices on alternative students with disabilities Mathematics achievement (Doctoral Dissertation), Northcentral University, San Diego, CA, USA. Retrieved from https://search.proquest.com/docview/1883356465

Radzi, R. M., Abdullah, M. N., \& Muruthi, K. (2017). Inquiry-discovery teaching approach as a means to remediate primary students' misconceptions about the Phases of the moon. Overcoming Students' Misconceptions in Science, 71-87. https://doi.org/10.1007/978-981-10-3437-4_5

Sommerhalder, M. (2018). Parents' supporting their adolescents' independent remedial Math practices: The effects of a multicomponent intervention package on Math academic performance (Doctoral Dissertation), University of Nebraska, Lincoln, NE, USA. https://digitalcommons.unl.edu/cehsdiss/306

Stevens, C. N. (2018). The effects of stress and growth mindset integration for students in remediation (Doctoral Dissertation), Grand Canyon University, Phoenix, AZ, USA. Retrieved from https://search.proquest.com/openview/86ccd7e4ed3141dcad81170 b09f55b68/1?pq-origsite=gscholar\&cbl=18750\&diss=y

Sultan, J. B. (2019). Characteristics of remedial students in learning numeracy and programs that enhance the achievement. Academic Research in Business \& Social Sciences, 9(5), 953-959. https://dx.doi.org/10.6007/IJARBSS/v9-i5/6023

Thilges, N., \& Schmer, C. (2020). A concept analysis of remediation. Teaching and Learning in Nursing, 15, 98-108. https://doi.org/10.1016/j.teln.2019.09.004

Triviño, P. C. (2016). The effects of remedial programs on the study of living things in the science achievement of Grade 2 students. e-Proceeding of the 4th Global Summit on Education. http://worldconferences.net/home

Tseng, S. F., Yu, L. C., Wu, H. S., \& Chao, P. Y. (2016). Measuring engagement: Student profiling and the effects if remedial learning counseling. The International Workshop on Learning Analytics and Educational Data Mining. Retrieved from https://inolab.slis.tsukuba.ac.jp/global/2016/LAEDM2016.pdf

Vandenbussche, J., Ritter, L., \& Scherrer, C. (2018). An incentivized early remediation program in Calculus 1. International Journal of Mathematical Education in Science and Technology, 49(8), 1235-1249. https://doi.org/10.1080/0020739X.2018.1458340

Wang, X., Sun, N., \& Wickersham, K. (2017). Turning Math remediation into "homeroom:" Contextualization as a motivational environment for community college students in remedial Math. The Review of Higher Education, 40(3), 427-464. https://doi.org/10.1353/rhe.2017.0014

Yolak, B. B., Kiziltepe, Z., \& Seggie, F. N. (2019). The Contribution of Remedial Courses on the Academic and Social Lives of Secondary School Students. Journal of Education, 199(1), 24-34. https://doi.org/10.1177/0022057419836434

Zygouris, N. C., Avramidis, E., Karapetsas, A. V., \& Stamoulis, G. I. (2017). Differences in dyslexic students before and after a remediation program: A clinical neuropsychological and event related potential study. Applied Neuropsychology: Child, 7(3), 235-244. https://doi.org/10.1080/21622965.2017.1297710 